\title{
ねじりピンテスト法による溶射被膜の付着強度評価に関する研究 Evaluation of Delamination Strength of Thermal Sprayed Coating by Torsion Pin-test Method
}

\author{
金子 堅司（東理大・工） 神川 雄次（東理大・院）榎本 和城（東理大・工）
}

To establish the adhesive strength evaluation method of thin coating layer with high adhesive strength, thermal sprayed coatings were tested by the newly proposed torsion pin test method. In this study, adhesive tensile strength of WC-12Co thermal sprayed coating is also investigated experimentally and analytically. Stress distributions at crack tip singular point on fractured interface are analyzed by FEM. It is found that the torsion pin test method is very useful to evaluate shear adhesive strength precisely by small number of specimen.

Key Words: Coating testing, Thermal sprayed coating, FEM analysis, Stress singularity, Shear adhesive strength,

\section{1. 緒 言}

近年溶射によるセラミック被膜技術は発展が著しく, ガスタービ ン翼・燃焼室壁や, 先端宇宙機器, ゴミ処理プラントのボイラーチ ューブ部などの過酷な環境下にさらされる重要な構造部への適 用が図られている.こうした被覆部品・機器の強度設計を精度よく 行うためには, 被膜と母体との付着力や被膜自体の破壇強度を 正確に知る事が必要である.

付着強度評価に従来からよく用いられるピンテスト法では, ピ ンの端面外周部(界面端部)において引張負荷によって引きはが し㤎弾性力学上無限大となり, 応力特異性が生じて強度が 低く出る. しかし, 応力特異場解析によって破壊力学的は解釈が 可能であることはすでに報告されており，ピン直径が異なる場合 でも応力拡大係数等で統一的な強度評価は可能とされている.

一方で, ピンテスト法はきわめて注意深い試料作成が求められ， ピンとピン穴との隙間やピン端面と母体の端面との高さのずれは 結果に大きく影響する. 要するに安定した強度評価が比較的簡 単に行える一般的な試験法としては難点がある.

本研究ではまずピンデス卜法において簡単でバラツキの少ない 結果を得る必要が求められていることに鑑み,ブラス卜処理の際 にブラストしない部分を作ることで人工的に初期き裂をつくり，応 力特異性の評価をしやすくした場合の検討を行った.

次に，引張ピソテススト法で測定される付着力は引張力によるものであるか ら, せん断付着力は評価できない. 通常の被膜させん断力によって剥離力゙生 じるものと考えられている,との批叛刘応するため, ねじり型のピンテス 卜法を提案し，実際に試験を行った結果について報告する.

\section{2. 試験片及び実験条件}

ジェットコートにより4段階の目標厚さに被膜した試験片ピン径 $\phi 2, \phi 3, \phi 4$ を用いピンを引き抜くことによって破断荷重を測定す るピンテスト実験を行う。
試験片材料
ブラスト材
溶射被膜
引張り負荷速度

\author{
SCM435 steel \\ アルミナ \#400 \\ $\mathrm{WC}-12 \mathrm{Co}$ \\ $0.5 \mathrm{MPa} / \mathrm{s}$
}

ピン径 (D)

溶射目標厚さ (t)

初期リングき裂幅 (a)

$\phi 2, \phi 3, \phi 4 \mathrm{~mm}$

$200,300,400,500 \mu \mathrm{m}$

$0.1 \sim 0.2 \mathrm{~mm}$

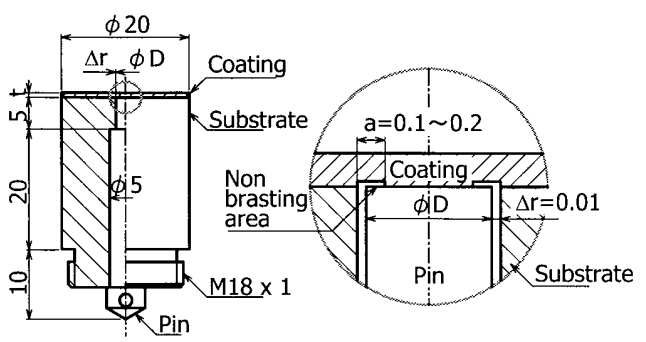

Fig.1 Pin-test specimen and the initial ring crack

\section{3. 解析方法}

解析には有限要素法ソフトMARCを用い，以下の条件で解析 を行う.

・等方弾性体とする.

- 二次元軸対称モデルとする.
・応力集中を受ける部分にはメッシュを細かくしてアスペクト 比を1に近づけている.

・ 全モデルに引張負荷応力 $20 \mathrm{MPa}$ を加える.

Table1. Mechanical Properties

\begin{tabular}{|c|c|c|}
\hline Materials & Young's modulus & Poisson's ratio \\
\hline SCM435 & $199000 \mathrm{MPa}$ & 0.25 \\
\hline WC-12Co & $999200 \mathrm{MPa}$ & 0.28 \\
\hline
\end{tabular}

\section{4. 引張り型実験と数値解析との比較}

\section{1 初期き裂長さが応力特異性に及ぼす影響}

図 2 に初期き裂長さを変化させたときのピンの界面端での主応 力分布の解析結果を示寸.き裂長さが増大寸るにつれて応力特 異性の影響が増大寸る. 実験結果はリング幅によって整理したが, き裂幅の増加により, 破断応力が低減し, バラツキが大きい結果 となった. ばらつきの少ない安定した結果は得られなかった。

\section{2 ピン径, 被膜厚さの影響}

図 3 にピン径を変化させたときの界面端からの距離と最大主忘 力の解析結果を示す.ピン径が増大するにつれて応力特異場の 影響も増大している結果となった. これは実験值の傾向とも一致 している.

図 4 に被膜厚さを変化させたときの界面端からの距離と最大主 応力との関係を表した解析結果を示す.被膜厚さが薄くなるにつ れて影響が大きくなっていて, 実験值の傾局と応力特異性の理 論と一致する結果となった。

\section{5. ねじり型試験の試験片と試験装置}

\section{1 ねじりピンテスト試験装置}

引張り型ピンテスト試験片をそのままねじり試験でき，し かも曲げ応力のかかりにくい孙じりの試験装置を試作した。

図 5 にその装置の概略を示す.試験片の本体を横向きに固 定しピンにリングを固定し，そのリングにビームを付け，ビ 一ム先端におもりを吊してピンをねじる構造になっている. 5.2 ねじりピンテスト試験片

直径 D:3mm のテーパーピンを用いた引張型のピンテスト 試料である.今回の検討ではピンとピン穴との隙間の影響を 確認するためにブラスト処理後ピン端面近傍外周をわずか に研削して様々な大きさのピン隙間の試料を用意した．図 6 にその状況を写真で示寸. 隙間 $\Delta r$ は数 $\mu \mathrm{m} \sim 60 \mu \mathrm{m}$ である.

\section{6. ねじりピンテスト試験結果および考察}

図7に試験結果を示す.横軸にはピンとピン穴との䏚間寸法を 示し, 縦軸には材料力学の公式による破断時のピン外周部のね じりせん断応力を示す. ねじり実験においておもりの追加は衝撃 がかからないように静かに行えばばらつきのない結果を得ること ができる.なお，行ったすべての試料について，破断面はピン外 周部において被膜とピンとの界面であることを確認した。

限界せん断応力は隙間の増大と共にわずかではあるが直線 的に減少している.これらの結果から最小自乗法で直線の式を 求めれば，隙間ゼロでの限界せん断応力を得ることができる.も っとも, 普通に試料を作れば隙間は $10 \mu \mathrm{m}$ 以下には収まるから その結果でもって隙閒ゼロでの結果としても実用上の問題は起き ないであろう. また, ばらつきが極めて小さいので従来の引張ピン 
テストのように多くの試料を用意して得られたばらつきの多い結 果を統計的に処理する必要もないと考える.

ちなみに，同じ試料を引張試験した結果は極めてばらつきが 大きく, 破壊面が界面ではなく, 被膜の内部で生じ, その様相も 試料ごとに異なることが確認された. 最近の高強度被膜では，界 面で剥離しないため益々引張ピンテスト法による結果の評価が 難しくなっていたことから，本研究で提案するねじりピンテスト法 は極めて有力な代換え案であると考える.

\section{7. 結言}

本研究では最近の強力な溶射被膜の付着強度を実験的に評 価する方法としてねじりピンテスト法を提案した。実際にねじりピ ンデスト装置を試作して実験を行った結果, 以下の結論を得た.

1. 引張ピンテスト法は一定の人工き裂を設置しても安定した結 果は得られず, 実験結果にはばらつきが大きい。

2. 例えピンとピン穴との隙間を厳しくコントロールしてばらつきの 少ない結果を得たとしても，それは応力特異場の影響を含んで おり, 付着力の評価は難しい.

3. 引張ピンテスト法で測定される付着力は引張力によるもので あるから, せん断付着力は評価できない. 通常の被膜はせん断 力によって剥離が生じるものと考えられている.

4. 最近の強力な付着力の溶射被膜の場合, 引張ピンテスト法で はピンと被膜の界面での剥離は生じないで, 被膜の内部での破 断が生じる場合が多く，正しく付着力を評価することができない.

5. 衫じりピンテスト実験では極めてばらつきの少ない結果が得ら れた.この理由は, 剥離が界面で生じること、被膜とピンの界面に 生じる冈周方向せん断応力には特異性が表れないことにある. 6. ピンとピン穴の誤差を様々に変えた実験結果では, あまり大き な差は出なかったが，一定の影響を確認できた.このことから,さ ほど精巧にピンテスト試料を作らなくても誤差の少ない結果が得 られることが分かった。

謝 辞 ねじりピンテスト溶射試料の作成にはトーカロ(株)の ご援助を頂いた.ここに記して深く感謝の意を表す。

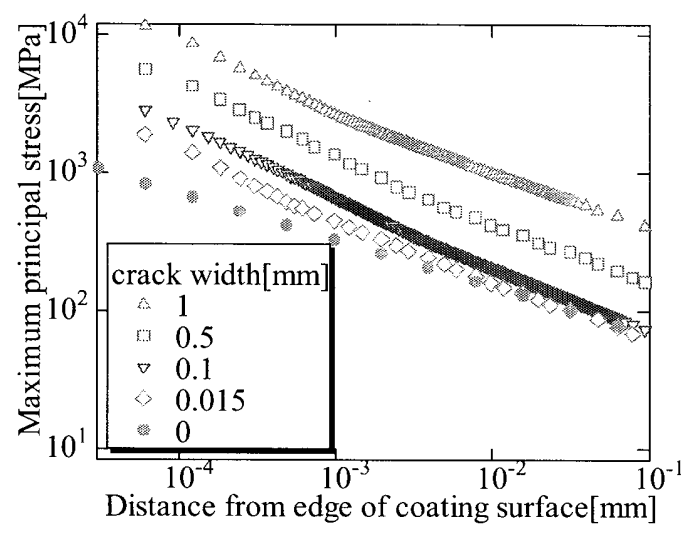

Fig.2 Influence of crack width of pin on stress singularity

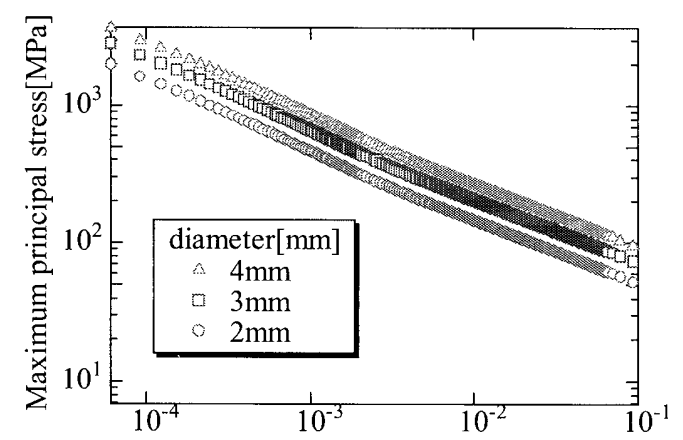

Distance from edge of coating surface[mm]

Fig.3 Influence of diameter of pin on stress singularity

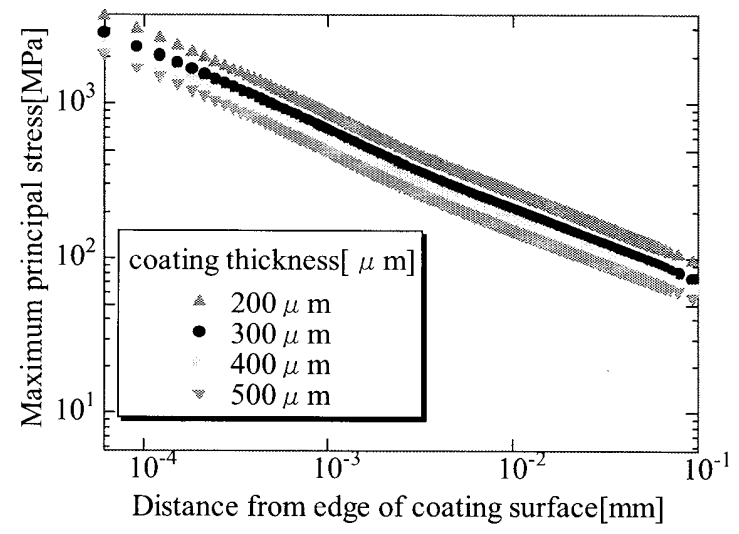

Fig.4 Influence of coating thickness of pin on stress singularity

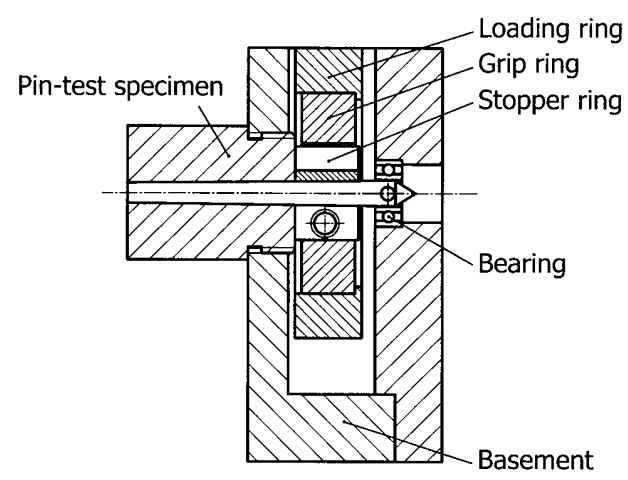

Fig.5 Apparatus of the torsion pin test

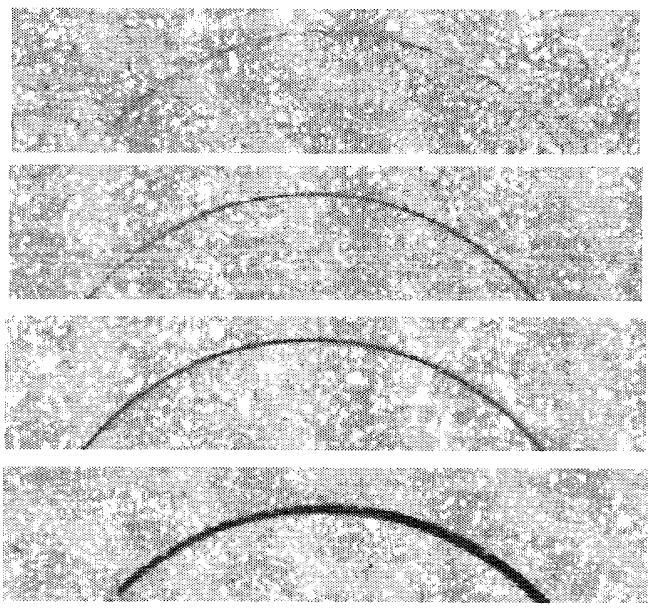

Fig.6 Views of the torsion pin test specimens of various clearances between pin and pin-hole

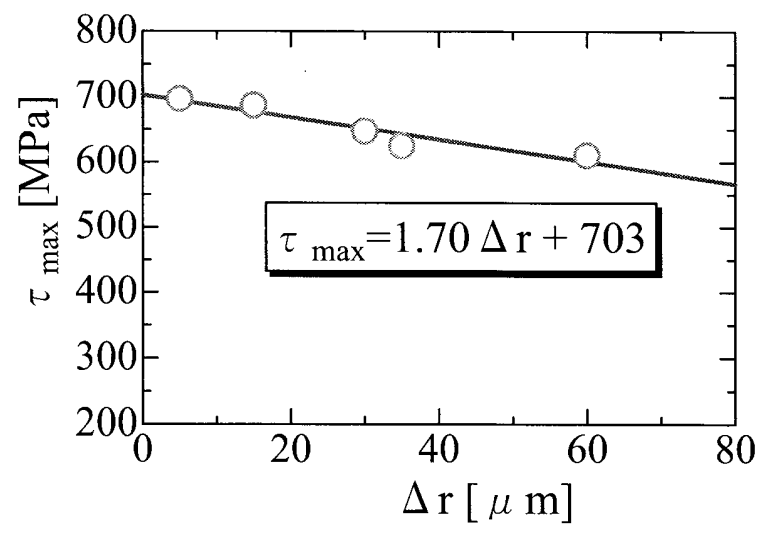

Fig.7 Experimental results on torsion pin test 